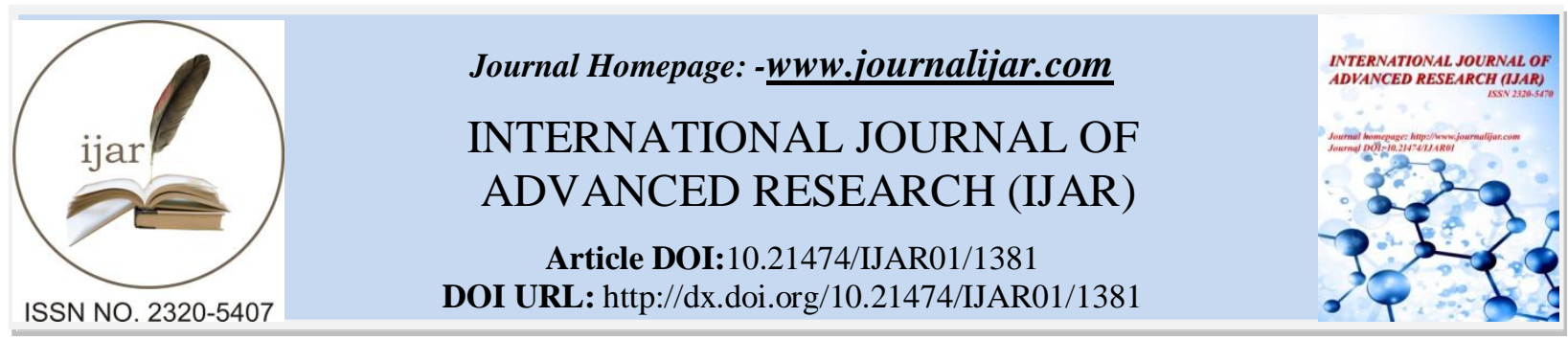

RESEARCH ARTICLE

\title{
STUDENTS' ASSESSMENT OF TEACHERS' ATTITUDES IN SECONDARY SCHOOLS IN ONDO STATE, NIGERIA.
}

Dr. Omoniyi A. Olubunmi (Mrs.)

Department of Science Education,AdekunleAjasin University,Akungba-Akoko, Ondo State, Nigeria.

\section{Manuscript Info}

Manuscript History

Received: 15 June 2016

Final Accepted: 19 June 2016

Published: July 2016

Key words:-

Students' assessment, teachers' attitude, capacitybuilding, provision of incentives.

\section{Abstract}

This study was designed to assess the attitudes of Nigerian secondary school teachersby their students in terms of the teachers' attitude to work, teaching and students. The study was a survey, and made use of a questionnaire tagged Students' Assessment Teachers Inventory (SATI),comprising 20 items, was used to collect data. The respondents were 2193 students which were randomly selected from 90 secondary schools. The SATI elicited information on different aspect of teachers' attitude to work, teaching and students. The study was guided by two hypotheses.

Data collected were analysed using Analysis of Variance, Pearson r, Means and Standard Deviation. The results from ANOVA $F_{2,2190}=$ $\left.3.00, \rho_{<0.05}\right)$ shows that there was no significant difference in the attitudes of different subject teachers to the teaching of science, social science and arts. Furthermore, the results showed that there was no significant relationship between teachers attitude to work $(r=0.343$, $\rho<0.01)$, teaching $(r=0.343, \rho<0.01)$ and students $(r=0.343, \rho<0.01)$. The study concluded that teachers' attitude to work, teaching and students in different subject areas was favourable, however, better performance could be achieved through capacity building and provision of incentives for teachers.

Copy Right, IJAR, 2016,. All rights reserved.

\section{Introduction:-}

Students' assessment of teacher is one of the most important approaches to teacher evaluation. Other approaches include principal assessment of the teacher, peer assessment, self-assessment and use of students test scores.

Students' assessment of teachers implies that students who are being taught by a teacher are made to express their opinions and feelings concerning the effectiveness of their teachers' instructional processes and activities over a period of time, and the extent to which they have benefitted from those processes and activities. Such students' opinions and feelings have been used as feedback data to improve instruction and enhance the professional growth of teachers. They have also been used as the basis or part of the basisfor personnel decisions like promotion, pay rise, dismissal and other forms of award /reprimand for the teacher that is being assessed. Thus, students' assessment of teachers' is a phenomenon and practice that has thrived over the years in the murky waters of controversy. It is one of the ways of holding teacher accountable to his/ her students.

Corresponding Author:-Omoniyi A. Olubunmi.

Address:-Department of Science Education,AdekunleAjasin University,Akungba-Akoko, Ondo State, Nigeria. 
Students' ratings/assessment of the teachersinstruction are used sometimes as a measure of the performance of the teacher from the students point of view. How can we be sure that we are doing a good quality job? Self-appraisal cannot be objective. Objective assessment can only be done by a third person (or persons) who can give objective feedback as to the quality of our output.

Good quality assessment is best performed by someone with:

a. an understanding of the parameters to be assessed

b. the competence to judge between "superior", "adequate" and "sub- standard" performance in relationship to the parameters, and

c. the ability to mitigate any bias in their assessmentand of course the time available to do the job well.

On the other hand, assessment constitutes a crucial part of quality assurance work. In higher education institutions in Nigeria, assessment in the pedagogical domain has usually been characterized by the traditional approach, a onesided assessment of students by the teachers. Over the years, research in education has shown that students' assessment of teachers improves the overall quality of teaching and learning (Urua, 2006).Black \& William (1998b) defined assessment "to broadly include all activities that students and teachers undertake to get information that can be used diagnostically to alter teaching and learning". The word "diagnostically" is crucial to draw attention to the fact that assessment is not an end to itself. Assessment may be for formative or summative reasons. Boston (2002) defined formative assessment as "the diagnostic use of assessment to provide feedback to teachers and students over the course of instruction". In the summative senses, it is used in formal reporting for perhaps disciplinary or promotional purposes. Evaluation is synonymous to assessment of appraisal, has been one instrument used in the personal public domain to assess work that has been done in order to attempt to determine and quantify the level of success or failure and to make improvements in the system.

As far as assessment is concerned, the traditional approach in educational institutions, including higher education institutions, entailed teachers' formal assessment of their students, for inspectors to assess the teachers, and so on. In essence, it was the case that a "superior" had the mandate of formally assessing the "subordinate", but not the other way round. It was therefore a one-sided approach, which did not provide holistic or comprehensive insight into the teaching and learning experience. Althoughstudents have always assessed the performance of their teachers, this has always been informal, behind the scenes and not used as adefinitive tool for formative or summative purpose.

Globally, the situation has changed drastically such that the "subordinate" can now assess the "superordinate". This is what we experience in modern educational institutions in the $20^{\text {th }}$ and $21^{\text {st }}$ centuries. Although, this is usually practiced in the western world, the traditional approach to assessment is still predominant in many higher education institutions in Nigeria (Urua, 2002).

\section{Rational for the Study:-}

Prior to this time, any failure or poor performance of students/learners was rarely officially blamed on the quality of teaching, teachers qualification and experience, infrastructure and so on, but mainly attributed to dullness and or lack of seriousness of the student/ learner. The blame has always rested squarely on the learner. Current research reports showing the impact of the quality of teaching, class management, teachers qualification and experience, mastery of the subject matter, teachers competence, pedagogical and communication skills of teachers, among others, have changed the perception and dynamics of education assessment (Garcia, 2003).

In Ondo State, there is a noticeable trend of laisser-faire attitudes of teachers to work which may have contributed to poor performance of students in external examinations (Omoniyi, 2013) hence, the study has the following research questions:

* What are the attitudes of teachers to teaching in different subject areas?

- What are the attitudes of teachers to work, teaching and students?

Two hypotheses were generated to guide the study

* There is no significant difference betweenteachers' attitudes to teaching in different subject areas.

* There is no significant relationship between teachers' attitude to work, teaching and students. 


\section{Methodology:-}

The study adopted the descriptive survey design. The study sample was 2,193 students in the state. The students were selected using stratified random sampling with school location as strata. An instrument, Students' Assessment Teachers' Inventory (SATI) was used to collect data. It consisted of 20 items, thatelicited information on the behavioural dispositions of the teachers. The SATI had an internal consistency reliability of 0.72 . Two hypotheses were tested for significance at $\rho<0.01$ level of significance using Analysis of Variance and Pearson-r.

\section{Results:-}

\section{Tables 1, 2 and 3 present the results of data analysis}

Table 1:-Mean Scores of different subject teachers to teaching.

\begin{tabular}{|l|l|l|l|}
\hline Variables & N & Mean & Std.Dev. \\
\hline Science & 865 & 21.03 & 1.90 \\
Social Science & 438 & 27.74 & 2.83 \\
Arts & 890 & 24.71 & 1.94 \\
\hline
\end{tabular}

Source: Authors' Field Work 2014

The result presented in Table 1 revealed that there was a significant difference in the Mean scores of attitude of teachers to teaching in difference subject areas. The mean $(\mathrm{X})$ of attitude of teachers to teaching in different subject areas ranged between 21.03 to 34.71 .

Table 2:-ANOVA Summary Table for attitude of different Subject teachers to teaching.

\begin{tabular}{|l|l|l|l|l|l|}
\hline Source of Variation & SS & df & MS & F-Cal. & F-Tab \\
\hline Between Groups & 0.444 & 2 & 0.222 & 0.2015 & 3.00 \\
Within Group & 2412.978 & 2190 & 1.1018 & & \\
Total & 2413.422 & 2192 & & & \\
\hline
\end{tabular}

Source: Authors' Field work, 2014

The results in Table 2 showed that $\mathrm{f}_{(2,2190)}=3.00, \rho<0.05$ of F-tab and $\mathrm{f}$-cal of 0.2015 indicating that F-cal is less than F-tab at 0.05 level of significance, meaning that there was no significant difference in the attitudes of science, social science and arts teachers to teaching. This implies that teachers subject area do not affect their teaching capacity.

Table 3:- Relationship between the attitude of teachers to work, teaching and students.

\begin{tabular}{|l|l|l|l|}
\hline Variables & $\mathbf{n}$ & $\mathbf{r}$ & $\rho$ \\
\hline Work & 2193 & 0.343 & $<0.01$ \\
Teaching & 2193 & 0.343 & $<0.01$ \\
Students & 2193 & 0.343 & $<0.01$ \\
\hline
\end{tabular}

The result obtained from Table 3 showed that there was no significant relationship between teachers attitude to work $(\mathrm{r}=0.343, \rho<0.01)$, teaching $(\mathrm{r}=0.343, \rho<0.01)$ and students $(0.343, \rho<0.01)$. This shows that there was nosignificant relationship between teachers' attitude to work, teaching and students.

\section{Discussion:-}

The analysis of data revealed that there was no significant difference in the attitudes of science, social science and arts teachers to teaching $\mathrm{F}_{(2,2190)}=3.00, \rho<0.05$ of F-tab and F-cal of 0.2015 , indicating that $\mathrm{f}$-cal is less than $\mathrm{f}$-tab at 0.05 level of significance. Furthermore, the results showed that there was no significant relationship between teachers' attitude to work $(r=0.343, \rho<0.01$, teaching $(r=0.343), \rho<0.01)$ and students $(r=0.343, \rho<0.01)$ indicating that there was no significant relationship between teachers attitude to work, teaching and students. All the three variables had positive relationship with teachers' attitude. However, teachers attitude could be influenced negatively by poor conditions of service, shortage of staff and non-payment of salaries. Therefore, for better performance, these attitudes could be enhanced by improving the condition of service for teachers through regular payment of salaries, increase in teachers' allowance, provision of incentives and capacity building for servicing teachers. Teachers' attitude towards teaching and learning has a significant impact in shaping the attitudes of 
students towards learning. This was supported by Joshua \& Joshua (2004. Students' positive attitude to learning could be enhanced through teachers helpful behaviour, resourcefulness, enthusiasm, good method of presentation, concern for students and teacher knowledge of the subject matter.

\section{Conclusion:-}

The quality of teaching depends on the love, dedication and commitment of teacher towards the subject.Students assessment of teachers attitudes to teaching is not only a timely academic discourse but also an urgent issue that requires the pragmatic attention and practical response by our Federal and State Government. The quality of teaching depends on the love, dedication and devotion of teacher towards the subject. Therefore, regular assessment of teachers by their students could enhance better performance and effective teaching and learning in schools. Also, effective supervision of teachers by the school management and Heads of Department could make the teachers to be more alive to their responsibilities. This will no doubt improve the quality of curriculum delivery and teachers output that would meet the set standards and expectations of the society. Teachers should be more encouraged to improve their attitudes towards their subjects in particular and teaching profession in general. During and after the course of their duties, how best to achieve the aims and objectives of an education system. This is in line with Odor (1995) when he emphasized that no matter the availability of educational infrastructure in the school system, they mean nothing, if there are no competent and committed teachers with positive attitudes. To ensure good performance of students, professionally qualified and highly motivated teachers are needed in our secondary schools. Therefore, there is a great need for a sound specialized background and professional training. In the same vein, Fafunwa (1991) affirmed that an unqualified teacher who delivers poor quality teaching is an enemy to the students' progress and a danger to the child's upbringing. Teachers have devastating effect on the intellectual, moral and emotional phases of the child's life.

It is recommended that teachers should be regularly assessed by their students to enhance positive attitude towards teaching since they are the role model. Finally, seminar/workshops on positive teachers' disposition while teaching should be addressed by all education stakeholders as important and urgent.

\section{References:-}

1. Ballou, Dale, William Sanders \& Paul Wright (2004): Controlling for student Background in Value-Added Assessment of Teachers, Journal of Educational and Behavioural Statistics 29/1:37-65.

2. Black, D \&Willam P, (1986b): Inside the black box: Raising standards through classroom assessment, phi Delta. Kappan 80/2: 139 -148 and http://www.pdk/nt/.org/1cappan/icblag810.htm- retrieved on 30/10/10

3. Boston, Carol (2002): The concept of formative assessment. Practical assessment, research and evaluation 8/a, http://PAREonline.net- retrieved on 12/07/10

4. Fafunwa, A. B. (1995): History of education in Nigeria ( $9^{\text {th }}$ ed.) Ibadan: NPS Educational publishers limited.

5. Garcia, Cathleen (2003): The effects of Teacher Attitude, experience, and background knowledge on the use of inquiry method. Teaching in the Elementary classroom. In partial fulfillment of the requirement in SCE 5308.

6. Joshua, Monday T. \& Akon M. Joshua (2004): Attitude of Nigerian Secondary School Teachers to Students Evaluation of Teachers, Teacher Development 1/1.67-79.

7. Kember, D., D. Y. P Leung \& K. P. Kwan (2002): Does the use of Student feedback questionnaires improve the overall quality of teaching? Assessment and Evaluation in Higher Education 27/5:411-425.

8. Odor, G. O. (1995): Administration of schools in Nigeria. Theory and practice. Benin-city: Momose Amalgamates.

9. Ololube, N. P. (2009). Understanding teachers' professional competencies for education effectiveness, Owerri: Springfield publishers Ltd.

10. Simmons, T. L. (1997): Student Evaluation of Teachers: Professional practice or pumitive policy? 1997.

11. Urua, Eno-Abati (2012). Advocating Student Evaluation of Teachers in Higher Education in Education: a pilot study. 